\title{
The Bay House Café: Against All Odds
}

\author{
Dudley-Anne Thomson, \\ Brian Finlayson and Michael Varekamp
}

D udley-Anne Thomson is the current manager of the Bay House Café, located10 kilometers from Westport, South Island, New Zealand. She rents the space from Brian Finlayson and Michael Varekam, who both started the Bay House Café eight years ago and then moved on to open restaurants in Sydney, Australia.

NEJE: Brian, the Bay House is located five hours driving time from Christchurch, the only major city on the South Island. The west coast of the South Island has a grand total of only 35,000 residents from Karamea in the north to Te Anu in the south. Many of the hundreds of kilometers of coastline are desolate. How did you pick this location?

Brian: I'm from the area originally, and I always thought the town of Westport, even with just 6,000 residents, could use an upscale café. We get an awful lot of tourists coming through from October through March when it's our summer, and I counted on that business as well. We typically closed the restaurant from April to September because we needed a chance to rest from a hectic summer season and to review our menu, promotional efforts, and past business strategies to plan on what we wanted to change.

The veranda we are sitting on and the inside dining area were added on to my batch (beach home) when Michael and I decided to start the café. I bought the batch 25 but decided only fairly recently to open up an upscale restaurant. It seemed like we could make a go of it.

Michael: The location, while away from the town, is spectacular. We are right across from a surfing beach, and the sunsets are a great selling point. Across the bay, we have a view of the Seal Colony where tourists by the hundreds walk every day to see the fur seals and their pups lying on the rocks. Can you think of a more beautiful place to eat a gourmet meal while looking out at the Tasman Sea?

NEJE: However, you have to admit, it must have been tough to attract enough business at first to make a go of it.

Brian: Actually, the tough part was working with the local town council to give us the necessary permits to open the café. It took six months to convince them to give us the go-ahead.

Michael: Everyone in town knew Brian, but they didn't know me. Outsiders, people who have not grown up in this area, are considered with great suspicion until the local townspeople feel they can trust you. If you're local, the council will bend the rules and even change the laws to help you out. However, I didn't have that advantage and the council, at first, interpreted the local ordinances in ways that were meant to stymie us.

Brian: The legal part took half a year of wrangling, but it took only three months to convert the front part of the batch into a restaurant and then add the deck. Once the Department of Conservation, which owned the land around the restaurant, gave us the final approval to proceed, we moved rapidly to start the café.

NEJE: It's one thing to get all the local town council approvals and convert the batch into a café, quite another to generate a positive cash flow.

Brian: That's true, but enough locals knew me from when I managed a restaurant in Westport called "Mandala's" to follow us out here. I also spent two years managing a bar/café in town called "Diego's." Originally, I had apprenticed as a pastry chef, then moved on to main courses, then eventually to managing the whole operation. I was ready to open up the "Bay House," and there was a built-in following.

Michael: In fact, there were so many people who wanted to come to the café, we were booked solid for three months and even had to turn people away.

\section{NEJE: It sounds like you started making money right away.}

Michael: Actually, everything cost us so much more than we had anticipated that we worked like dogs just to pay off the $\$ 40,000$ (New Zealand) we needed to borrow to construct the dining area. The second year of business we broke even and had all our debts paid off.

Our location has superb views, but the downside was 
we were on a dirt road with no electricity and no local water, at least not enough to operate a café. We faced a lot of up-front expenses before we even served our first meal.

Brian: We probably would have achieved break-even sooner, but we underpriced ourselves in the marketplace. We weren't charging enough for our lunches and dinners. Breakfast seemed okay, but we were not making sufficient margin on the other meals. We had put together a business plan, this is something I learned how to do because I worked for a U.S. firm as a product manager for several years; but we made some costly errors in the beginning.

\section{NEJE: How long did you own and manage the café?}

Michael: Five years, and we became enormously successful at it. However, I'm from Sydney and I missed the city. I convinced Brian to lease out the restaurant, keep the batch, and move to Sydney. Brian agreed, and we opened up the "Chocolate Dog Café" in the Rocks Section of the city.

NEJE: After struggling to establish the Bay House Café, you left it to start another venture? Why not just ride your first success and coast for awhile?

Brian: We wanted to challenge ourselves and see if we could establish a successful restaurant in a large, cosmopolitan city like Sydney. "The Chocolate Dog" was open seven days a week. The café was well accepted by the locals as well as tourists, and we did extraordinarily well. I really like to create spaces where I can entertain people and see them enjoying themselves. The experience was very fulfilling. I loved it.

\section{NEJE: And that's where Dudley-Anne comes in. You sold} the business to her.

Michael: Hmmm ... not exactly. I only wish we had.

Brian: What happened was we sold the café to an Australian entrepreneur who made all sorts of noises about all this experience he had and what he could do for the restaurant to expand it and to make it even more profitable. Turns out, he ran up debt all around Westport, never paid it off, and pretty much was an absentee owner from the git-go.

Michael: We knew we had a serious problem within 60 days of handing over the café to this guy. Our friends in town called and told us the food quality and service were going down rapidly. The fellow didn't seem to care about the café's image, nor return phone calls about when he was going to pay for the merchandise and services he had purchased.
Dudley-Anne: Now that's where I come into the picture. Mark, who at the time three years ago was my boyfriend and business partner, and I were looking to move to the Westport area. Mark, and I'd rather not provide his last name, grew up here and has close family ties around Westport. Neither of us knew much about the Bay House Café. I had grown up in Hastings on the North Island of New Zealand and hadn't traveled much in the South Island. I did have restaurant experience, and that's to the good; but Mark and I did not have a good enough credit rating to borrow the money to buy the Bay House. That's where our financial "angel" came in.

While in the North Island, Mark and I met an American fellow who so took to us that he promised to put up money for a business we might want to buy some day. Well, when we found out the Bay House was up for sale, we called him and told him we were ready to call him on his offer to back us. He was surprised at first that we were ready to take him up on his promise; but he followed through just as he said he would, and we bought the business.

Brian: We tried to talk Mark out of buying it, though, because we were ready to throw out the Aussie chap since he wasn't paying the monthly rent to us. We never got a penny from that guy after he purchased the café. Nothing in three months. But Mark wouldn't listen to us and insisted on buying the business outright from the owner who charged him twice what he had paid us. What a waste of money.

Dudley-Anne: I didn't know anyone in town except Mark and his family; they lived around the Westport area so I just followed his lead. That proved to be unfortunate. At the beginning, Mark was the chef and I took care of the front operation. It took me two years just to get to know the local market enough to where I was sufficiently confident to start making changes.

But talk about surprises. We went into the café expecting to use the kitchen equipment only to find out that some new equipment included in the sale didn't belong to the seller. They were never paid off, and some people showed up ready to cart them away. It was a tough start.

\section{NEJE: What changes did you make?}

Dudley-Anne: For one, getting rid of the tour buses that would stop off, discharge dozens of passengers who would monopolize the café, order a soda and perhaps a scone, stay for an hour or two to fill out their postcards, 
and then move on. The buses were a nuisance, the margins on soda and scones low; and this discouraged local trade from coming out here.

We are not a tea café. We serve gourmet meals at competitive prices, but this means attracting a market that wants excellent food and service and a fairly quiet environment. The buses were ruining that.

Everyone in Westport thought I was crazy; but I had a long-term vision of the business and where I wanted to take it, and the tour buses did not fit into that vision. Mark and I tried to stay open during the winter months here, but after two years we gave up. We were serving too few meals and lost a lot of money because we couldn't meet the overhead. Now, we close from May to August to replenish our energies, conduct needed maintenance, and get ready for the busy summer seasons.

\section{NEJE: Did you also put together a business plan like} Brian and Michael did?

Dudley-Anne: Yes, we did; but it was more to please our financial backer than to guide our everyday activities. Recently, though, we put together a new business plan because it was required by the government as part of our application to win one of the national "Tourism Awards" given out by the New Zealand Tourism Commission. Mark thought the effort wasn't worth it; but I was more sensitive to the marketing value of the award, and so I decided to go after it. We hired a consultant from Christchurch, and he guided us through the planning process.

To our great surprise, considering the commission representatives came to see the café during the winter months when we weren't serving meals, we won "Best Café" for our size for the west coast of the South Island out of 32 entrants. This award, and the other tourism awards we've won since, has given us much greater visibility than we ever had before. We are now attracting an international clientele.

NEJE: That must have convinced Mark you were right to invest the time and money to apply for the awards.

Dudley-Anne: No, Mark and I ended our personal relationship 18 months ago because we just didn't share the same vision for the café and for our personal lives. We continued to run the business for the next year together, but it became really hard. Mark didn't like sharing the kitchen operation with anyone else; but as we got busier and busier, he couldn't manage it all. We needed other chefs in the kitchen to handle the volume, but he kept worrying about spending more money on additional staff.
Mark saw his job as a "9-to-5" operation, and you can't do that when running a restaurant. It's flat-out 7 days a week, an 18-hours-a-day job. You can't avoid it if you want to be successful. He only wanted to cook at certain times of the day, and that really limited our menu.

Mark left the business for good about four months ago, and I must say, I couldn't have been more relieved. I am happier now than I've ever been; the business is completely mine to run, and I don't have to check in with him any more. No more hassles and fights about how the restaurant should operate. I love it!

The café now has more of a "lady's touch" to it and the restaurant is much more tidy and attractive than it used to be. I really look after the "front of the house," so to speak, and rearrange the lounge every other week to keep things looking new and different to our regular customers. They seem to appreciate that.

I've also increased the number of meals we can serve on any given night by making sure the tables turn at least twice; there's a 6 to 6:30 PM sitting and another one at 8:30 PM. If guests continue to linger at their tables past 8:30, we ask them to take their dessert and coffee to the lounge. That way we keep things moving. We just had the best Saturday night we've ever had this past weekend. The velocity of our business has picked up considerably.

NEJE: What market research have you conducted? Have you advertised regularly?

Dudley-Anne: We did conduct a survey of local motels about who their clientele was and we asked our diners how they had heard about us. We thought we should provide incentives to the moteliers to send their guests to us, but after a bit, we realized that the motels in the area were getting calls from customers who first made dinner reservations with us, then called around for a place to stay.

We did not advertise the first two years we were in business; we were depending on word-of-mouth. Now we advertise in local publications, and we're part of the "pure New Zealand" website. We also have our own website (dine@bayhousecafe.co.nz).

\section{NEJE: Do you have trouble keeping staff?}

Dudley-Anne: Not at all. We're all pretty close. Communication is key, and I ask my staff on a regular basis to "yarn it out" - to tell me what is bothering them, what concerns they have, and what suggestions they have to increase business. Listening is a skill that every small business owner should have. 
NEJE: How long do you want to continue managing the Bay House?

Dudley-Anne: I've built it up through a ton of hard work, and now it's my baby. It's me. If I leave, what will happen to the Bay House and to my customers? As we've gotten more successful, I've left more and more of the day-to-day operations in the hands of the staff. That gives me more freedom to relax and not feel as much anxiety and tension as I used to. I can travel a bit more during the summer season and that's nice, too.

NEJE: What keeps you fellows in the restaurant business in Sydney?

Brian: Well, actually right now we're taking a breather. We've sold the "Chocolate Dog Cafe," and we're thinking about what to do next. For me, though, being in my own business means I don't have a boss looking over me. I like to take on the challenge of creating a new business from scratch and seeing if I can make a lot of folks happy by entertaining them and serving good food at the right price.

Michael: For me, I like seeing customers enjoy what I've been able to create. I love receiving compliments on what we've designed either from an original concept or from taking an existing business and moving it from "point A" to "point B." The fun is in the process. Once we achieve our goals, I'm ready to move on. I look forward to the next project and the next success. That's what keeps me motivated. 